\title{
Constraints on the origin of south indian magnesite deposits
}

\author{
V. PRASANNAKUMAR; C. VIKAS ; S.N. KUMAR* \\ University of Kerala, Kariavattom, Trivandrum, 695 581, India; vprasan@vsnl.com \\ *University College, Trivandrum, 695 034, India
}

(Received November 2002 Accepted December 2002)

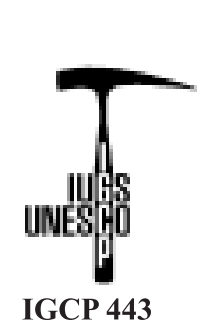

\begin{abstract}
Most of the magnesite deposits in South India are confined to the southern part of the Dharwar craton and are associated with the ultramafics emplaced into the older supracrustal rocks. The major mineralisation is located in a shear zone that separates the Early Proterozoic and Pan-African granulites. The timing of mineralisation and the source of carbon for the various magnesite deposits of South India are points of debate. Temporal relations of deformation, metamorphism, incipient charnockitisation and mineralisation in the shear zone have been analysed. On the basis of the $\mathrm{CO}_{2}$ influx, which favoured the formation of incipient charnockites, it is presumed that a juvenile $\mathrm{CO}_{2}$ rich solution might have significantly contributed to the source of carbon for magnesite mineralisation. The present study attributes the timing of magnesite mineralisation to Pan-African time.
\end{abstract}

Key words: Magnesite, ultramafics, juvenile source, shear zone, Pan-African time, South India.

\section{Introduction}

Vein type magnesite deposits in Precambrian ultramafic rocks of South India contribute the major portion of magnesite in India. The South Indian shield, once considered as accreted during the Archaean, is recently being treated as a mosaic of several crustal blocks with contrasting geological and geochronologic signatures ranging from Archaean to Proterozoic (Newton \& Hansen 1986; Harris et al 1994). Two major Proterozoic shear systems viz. Palghat Cauvery shear zone and Achankovil shear zone (Fig.1), dissect the terrain, of which the former acts as a terrain boundary between the Early Proterozoic northern granulites of about 2.5Ga (Friend and Nutman 1992) and the southern granulites of Pan-African age close to $0.55 \mathrm{Ga}$ (Bartlet et al 1995). This major crustal discontinuity in South India hosts acid to ultrabasic intrusives as well as mineralisations of magnesite. The ambiguities in the interpretation of the kinematics of the shear zone impose constraints on the timing of mineralisation and correlation of the Precambrian rocks of South India with other Rodenian continents. Major magnesite deposits of South India occur in Tamil Nadu and Karnataka, out of which the former is sitauated in the shear zone and the latter to the north of the shear. Though the various

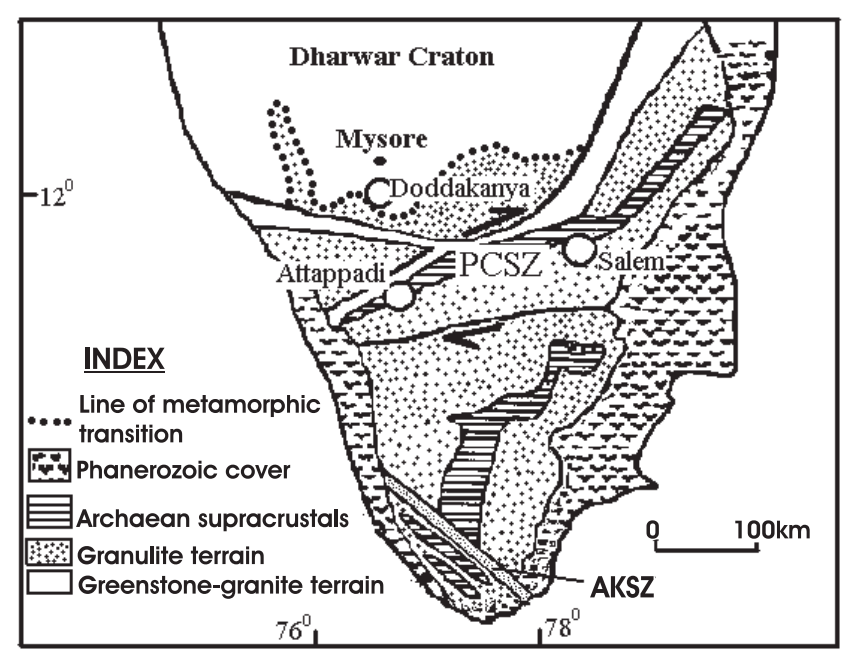

Fig. 1. Location of Palghat Cauvery (PCSZ) and Achankovil (ACSZ) shear zones.

deposits were subjected to detailed study regarding their economic potential and type of mineralisation, opinion differs as to whether they are genetically related to weathering of ultramafics by downward percolating solutions or formed due to reaction of late stage comagmatic hydrothermal fluids with the host ultramafic rocks. Various aspects of the different deposits are examined with a view to bring out the constraints on the origin of the deposits. 


\section{Geological setting}

Magnesite deposits of South India are located in the amphibolite-granulite facies transition zone, which lies in between the low-grade granite-greenstone terrain to the north and the high-grade granulite terrain to the south. Magnesite mineralisation in South India is mostly associated to the rocks of the ultramafic intrusive complex, forming a part of the metamorphosed volcanosedimentary supracrustal rocks. The ultramafic complex is composed of dunite, peridotite, pyroxenite, gabbro and their metamorphic products (Fig.2). Carbonatite and anorthosite are also observed associated with the ultramafic complex. Geochemical characteristics suggest a tonalite-trondhjemite composition for the gneiss and tholeiitic basalt parentage for the amphibolite (Prasannakumar et al 1990, 1994). A phase of postmetamorphic juvenile magmatism is indicated by the occurrence of granites and migmatites in the shear zone.

Polyphase deformation and metamorphism has resulted in the formation of three generations of folds, differing in tectonic style and orientation, as well as structures characteristic of shearing (Nair et al. 1981;
Eric D' Cruz et al 1999). The shear zone rocks exhibit both mesoscopic and microscopic features typical of deformation by ductile shearing and rocks ranging from protomylonite to ultramylonite are present. The strong flattening of the fabrics parallel to the shear plane is suggestive of simple shear deformation. While the majority of the mesoscopic and microscopic shear-sense indicators, including porphyroclasts and crystallographic preferred orientation, points to a dominant dextral sense, some of them reflect sinistral sense also. The movement picture on the bulk scale, derived by the integration and comparison of spatial and temporal kinematic history of different microdomains, suggested an early dextral movement overprinted by a later sinistral sense probably during the Pan African time (Prasannakumar 2002).

\section{Mineralisation}

Mineralisation of magnesite is observed at different places along the shear zone. Chalk hills, Salem, Tamil Nadu, host the major magnesite deposit in South India. Vein type magnesite mineralisation is confined to

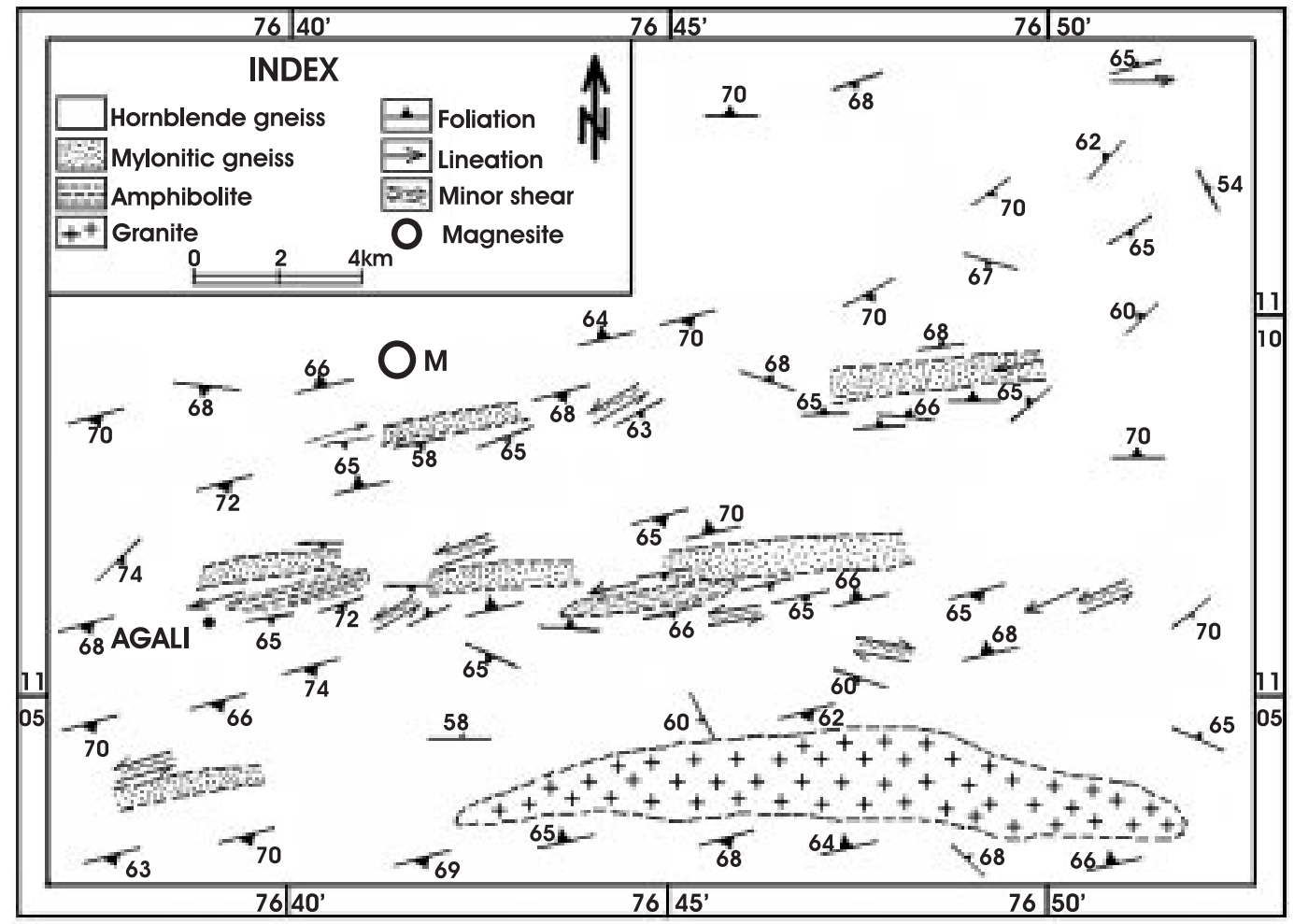

Fig. 2. Geological map of a part of Palghat Cauvery shear zone. 


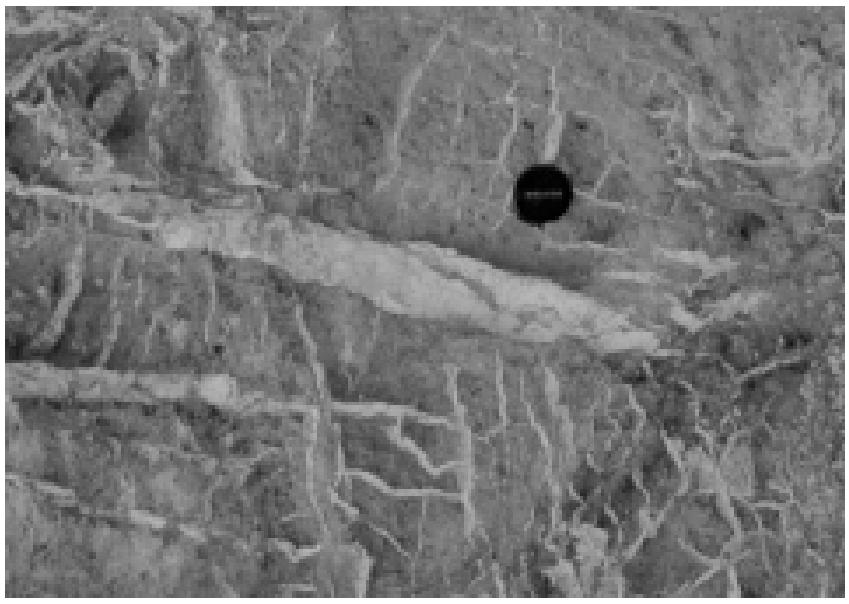

Fig. 3. Magnesite veins in serpentinised and weathered ultramafics

fractures in the dunite and peridotite and is restricted to extensively serpentinised and weathered portions of the ultramafics (Fig.3). Massive, granular as well as fibrous types of magnesite are observed in subhorizontal to steeply dipping veins. Of these the granular type is most common and contributes most to the economic deposits while the massive type is less abundant and is composed of cryptocrystalline magnesite exhibiting porcellaneous lustre. The economic grade magnesite is often restricted to a depth of about $50 \mathrm{~m}$. Vein type magnesite deposits hosted by ultramafics in the Chalk hills of Salem, Tamil Nadu, are emplaced along NE -SW trending shears/ fractures (Sethumadhav \& Govindaiah 1998). Magnesite mineralisation is confined to the central and northern parts in Attappadi, at the western part of the shear zone. Magnesite veins occur in lenticular peridotite, composed mostly of olivine and subordinate clinopyroxene, enclosed in hornblende gneiss and amphibolite (Fig.4). The highly weathered peridotite lens generally follows the ENE-WSW trend of the shear zone fabrics (Prasannakumar \& Nair 2000). Recently, compelling evidences have been obtained from the area to consider the dunite and peridotite as a part of an ophiolitic sequence. In Doddakanya, Karnataka, magnesite is confined to c.3.3Ga old ultramafic body constituting a dismemebered part of a layered ultramafic-mafic complex emplaced into the older supracrustals (Krishna Rao et al 1999).

\section{Genesis of magnesite}

Though the major magnesite deposits of South India have similar geological setting, both upward injections

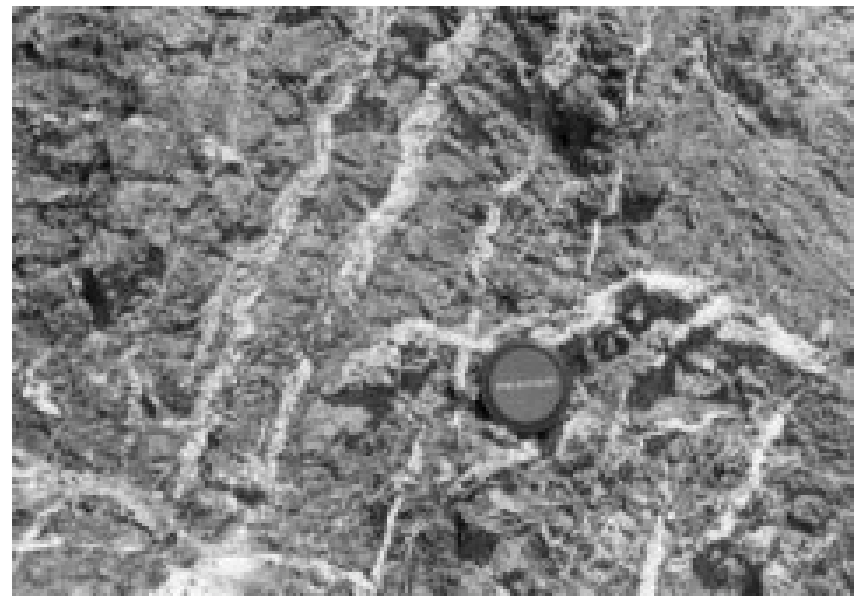

Fig. 4. Magnesite veins

of $\mathrm{CO}_{2}$ rich fluids as well as downward percolation of mineralizing solutions have been suggested as plausible mechanisms for the genesis of magnesite associated with the ultramafics. Magnesite at Salem is generally considered to be formed due to the reaction of late stage co-magmatic hydrothermal fluids with the host ultramafic rocks, though the source of $\mathrm{CO}_{2}$ still remains uncertain. However, regarding the deposits at Doddakanya, Karnataka, opinion differs. Following the proposition of the activity of ascending $\mathrm{CO}_{2}$ rich solutions for the granulite metamorphism and formation of charnockite in South India, it was suggested that the high grade metamorphism of ultramafic rocks accompanied by the ascending $\mathrm{CO}_{2}$-rich fluids can lead to the formation of magnesite along with pyroxenes. However, the model was refused and it was suggested that the ultramafic body hosting the magnesite deposits of Karnataka was subjected to a near-surface low temperature serpentinisation and during subsequent weathering downward percolating $\mathrm{CO}_{2}$ rich meteoric waters reacted with the host rocks under ambient temperature conditions to produce magnesite (Krishna Rao et al 1999). Though different levels of serpentinisation have been observed in various localities there are undisputed instances of magnesite mineralisation in dunite and peridotite which do not show serpentinisation. Hence it is worth examining the formation of such magnesite in dunite and peridotite since magnesite and quartz can be directly formed by the interaction of $\mathrm{CO}_{2}$ bearing water vapour and ferromagnesium minerals without passing through the intermediate serpentine stage. 
Ultramafic rocks hosting magnesite mineralisation have been subjected to different degrees of serpentinisation during different events. Evidences for an earlier high temperature event with antigorite and a later near surface event with formation of chrysotile have been postulated by different authors. This is further evident from the restriction of mesh-textured serpentinite to the upper and near surface levels. Restriction of economic grade magnesite veins to the upper $40-50 \mathrm{~m}$ depths and their abundance in the intensely weathered and serpentinised portions of the ultramafics and presence of dehydration cracks implies that the formation of magnesite took place under nearsurface temperature conditions. Further, petrographic studies support the formation of magnesite during the waning stages of metamorphism. Early Paleoproterozoic high-grade metamorphism around $2355 \pm 18 \mathrm{Ma}$ is evidenced by granulite remnants in the shear zone. An age of $1705 \pm 11$ Ma has been given by relict charnockite for late Paleoproterozoic metamorphism, while garnet crystallization age from post-deformation pegmatite in the zone gave $513 \pm 5 \mathrm{Ma}$. Hence it is probable that major deformation and metamorphism occurred around $1705 \mathrm{Ma}$ and the deformation outlived metamorphism. Detailed studies on metamorphism reveal that highgrade metamorphism operated at a temperature of 614 to $800^{\circ} \mathrm{C}$ and pressure of 7.1 to $7.4 \mathrm{kbar}$ in the presence of ascending $\mathrm{CO}_{2}$ rich solutions. Geochronologic data on the Peninsular Gneiss and granulites from the northern and southern blocks of the shear zone suggest that the Archaean continental crust in South India was subjected to a major long-lived thermal event at $\mathrm{Ca}$. $2.51 \mathrm{Ga}$ followed by slow cooling until Ca.2.1 Ga (Mohan and Jayananda, 1999), which indicates that the shearing is probably later than $2.1 \mathrm{Ga}$.

\section{Source of magnesium}

Ultramafic rocks are considered to be the source of magnesium required for the vein type magnesite deposits in different parts of the world. Though magnesium is released during weathering and serpentinisation of dunite and peridotite, it is insufficient to account for the magnesite deposits at depth, especially in the zone of less weathering and serpentinisation. Magnesium is also released by the breakdown of silicates due to hydrothermal activity associated with ultramafic-mafic magmatism.

\section{Source of carbon}

Various models are in vogue regarding the source of $\mathrm{CO}_{2}$ for the formation of vein-type magnesite deposits. Of these, magnesite formation as a result of reaction of ultramafic rocks with ascending $\mathrm{CO}_{2}$ - rich diagenetic metamorphic fluids derived from decarbonation of deep-seated carbonates or decarboxylation of organic rich sediments was in wider acceptance (Pohl 1990). The other mechanisms include meteoric waters enriched with atmospheric or biogenic carbon (Jedrysk \& Halas 1990) a mantle source for the carbon (Gold 1979) and mixing of ascending fluids with near surface meteoric water constituting the mineralizing solution. The complexity and proliferation of models often makes it difficult to suggest a model without ambiguity and in recent years carbon isotope studies have been resorted to for constraining the genetic model. Carbon isotope studies of the Doddakanya magnesite indicate a narrow range from -2.27 to $-2.97 \%$ ruling out the possibility of carbon contribution from more than one source. Further the values have been compared with those of calcrete and soil carbonates of modern sub-humid climates and it has been suggested that the $\mathrm{CO}_{2}$ required for the formation of magnesite was derived from a biogenic soil source (Krishna Rao et al 1999). Besides, they have suggested that the timing of magnesite formation is not to be older than $8-7 \mathrm{~m}$.y. The lack of isotopic studies of the deposits at Salem as well as Attappadi makes it difficult to propose a similar model or to contradict the proposed model. However, indirect evidences like the fluid inclusion studies on auriferous quartz veins from the shear zone suggest that the dominant fluid responsible for the gold mineralisation was moderately dense regarding $\mathrm{CO}_{2}$, with variable proportion of $\mathrm{H}_{2} \mathrm{O}$. Fluid inclusion carbon isotope studies indicate that the $\delta^{13} \mathbf{C}$ values range between -5.9 and -9.4 , mostly -5 and -7 , corresponding well with the isotopic composition of carbon in kimberlites, carbonatites and $\mathrm{CO}_{2}$ outgassed from ocean island basalts.

The $\mathrm{CO}_{2}$ in the veins was probably derived from an outgassing subcontinental upper mantle. Generally, metamorphic decarbonation of marine carbonates produces positive $\delta^{13} \mathbf{C}$ values. However, carbonate minerals associated with gold deposits display a tight range of carbon isotope values between -2 and -4 . Carbon isotope studies also favour a juvenile mantle 
source for carbonic fluids, which were instrumental for the generation of vein-gold deposits. Several studies in South India have envisaged $\mathrm{CO}_{2}$ influx for the formation of Pan African granulites. All these point to the activity of upward moving $\mathrm{CO}_{2}$-rich fluids, derived from the mantle with the potential to leach out, concentrate and relocate ions. The shear system in all probability might have acted as the pathways for magma migration, fluid propagation and mineralisation. The collision of different crustal blocks, overthrusting, granulite formation in the lower crust, development of shear zones, partial melting, high heat flow and release of $\mathrm{CO}_{2}^{-}$ rich fluids have all played significant roles in the leaching, transportation and localisation of mineral deposits including magnesite.

\section{Discussion and conclusions}

The temporal relations of deformation, metamorphism and mineralisation, worked out on the basis of structural analysis reveal that the first phase of the deformation was synchronous with metamorphism and subsequent ductile shearing with a dextral sense.
Though there are evidences in favour of both dextral and sinistral sense, a bulk dextral movement, probably in the late Proterozoic at ca $1705 \mathrm{Ma}$ and reactivation with sinistral sense, during Pan-African time, seem to be the most appropriate shear zone kinematics. Mineralisation of gold and tungsten possibly involved leaching and remobilization from a tholeiitic basalt source during regional metamorphism and shearing deformation. Magmatic underplating at the base of crust and the $\mathrm{CO}_{2}$ rich fluids released from underplated magma would drive dehydration reaction by buffering the water activity to low levels, thereby generating granulites. $\mathrm{A} \mathrm{CO}_{2}$ rich juvenile environment further suggests that the carbon required for the formation of magnesite could be derived from a mantle source. Localisation of magnesite veins along fractures in peridotite is the youngest mineralisation event in the zone. Since the weathering that produced magnesite at Doddakanya is considered to be not older than 8-7 Ma, more detailed study incorporating isotope analysis of carbon and oxygen are being undertaken to precisely constrain the source of carbon and time of magnesite mineralisation in South India.

\section{References}

Bartlet J.M., Harris N.B.W., Hawkesworth C.J. \& Santosh M. 1995. New isotope constraints on crustal evolution of southern India and Pan-African metamorphism. Memoir Geol. Soc. India, 34, 391-397.

Eric D' Cruz., Nair P.K.R. \& Prasannakumar V. 2000. Palghat Gap- a dextral shear zone from the south Indian granulite terrain. Gondwana Research, 3, 21-31.

Friend C.R.L. \& Nutman A.P. 1992. Response of U-Pb isotopes and whole rock geochemistry to $\mathrm{CO}_{2}$ induced granulite metamorphism, Kabbaldurga, Karnataka, south India. Contribution to Mineralogy and Petrology, 111, 299-310.

Gold T. 1979. Terrestrial sources of carbon and earthquake outgassing. Jour. Petrol. Geol., 1, 3-19.

Harris N.B.W., Taylor P.N. \& Santosh M. 1994. Crustal evolution in south India: constraints from $\mathrm{Nd}$ isotopes. Journal of Geology, 102, 139-150.

Jedrysk M.O. \& Halas S. 1990. The origin of magnesite deposits from the Polish Forsesudetic block ophiolites: preliminary $\mathrm{d}^{13} \mathrm{C}$ and $\mathrm{d}^{18} \mathrm{O}$ investigations. Terra Nova, 2, 54-159.

Krishna Rao B., Sethumadhav M.S., Hanuma Prasad M., Mahabaleswar T.D., Rao A.V. \& Gilg H.A. 1999. Features and genesis of vein-type magnesite deposit in the Doddakanya area of Karnataka, India. Jour. Geol. Soc. India, 54, 449-465.

Mohan A. \& Jayananda M. 1999. Metamorphism and isotopic evolution of granulites of southern India: reference to Neoproterozoic crustal evolution. Gondwana Research, 2, 251-262.

Nair P.K.R., Prasannakumar V. \& Thomas Mathai. 1981. Structure of the western termination of the Bhavani lineament. Jour. Geol. Soc. India, 22, 285-291.

Newton R.C. \& Hansen E.C. 1986. The south India-Sri Lamka high grade terrain as a possible deep crust section. In- The nature of the lower continental crust, (Ed.) Dawson J.B., Carswell D.A., Hall J. \& Wedepohl K.H. Geological Society Special Publication, 24, 297-307.

Pohl W. 1990. Genesis of magnesite deposits: models and trends. Geol. Rund., 79, 291-299.

Prasannakumar V., Nair P.K.R. \& Eric D' Cruz. 1990. Amphibolites of the Marutha gold prospect in the Precambrian high grade terrain of south India. Jour. Geol. Soc. India, 35, 514-519.

Prasannakumar V., Nair P.K.R. \& Eric D’ Cruz. 1994. Geochemistry and origin of granitoids of Marutha gold prospect, Kerala. Indian Journal of Geochemistry, 9, 13-20. 
Prasannakumar V. \& Nair P.K.R. 2000. Tectonic control of magnesite mineralisation in Bhavani shear zone, South India. Mineralia Slovaca, 32, 565-566.

Prasannakumar V. 2002. Shear zone kinematics and tectonic control of gold, scheelite and magnesite mineralisation. Special publication of the Australian Institute of Geoscientists, 36, 167168.

Sethumadhav M.S. \& Govindaiah S. 1998. Seprpentinisation and magnesite mineralisation at Chalk hills, Salem district, Tamil Nadu. Indian Mineralogist, 32, 87-88. 